Ramsar Lakes in the Foothills of ...

\title{
Review Article \\ Ramsar Lakes in the Foothills of Himalaya, Pokhara- Lekhnath, Nepal: an overview
}

\author{
Namita Paudel $^{1 *}$, Subash Adhikari1 ${ }^{2}$, Ganesh Paudel ${ }^{3}$ \\ 1 Institute of Tibetan Plateau Research, Chinese, Academy of Sciences, \\ Beijing 100101, China \\ 2 Tribhuvan University, Janapriya Multiple Campus, Pokhara, Nepal \\ 3 Tribhuvan University, Institute of Forestry, Pokhara, Nepal \\ *Correspondence-n.paudel@itpcas.ac.cn
}

\begin{abstract}
Wetlands are the most dynamic ecological units on the earth delivering voluminous ecosystem services. Pokhara-Lekhnath has prosperous wetland ecosystems with nine lake clusters nominated as $10^{\text {th }}$ Ramsar site of Nepal in 2016 that act as diverse and, distinctive biodiversity hot spot and habitat. These wetlands afford abundant ecosystem services and assist vulnerable, endangered and critically endangered species. However these lakes are under tremendous pressure due to rapid urbanization, natural erosion, encroachments, land use changes in the catchment and anthropogenic inputs resulting in the shrinkage of area and deterioration in the hydrological, economic and ecological characteristics.
\end{abstract}

Keywords: Pokhara-Lekhnath; Ramsar sites; bBiodiversity hot spot; ecosystem; lentic

\section{Introduction}

As per the definition by EPA, the wetland is an area where either water covers soil or remains in the proximity of soil for at least one season. Basically, the wetland is land area saturated with water and is ecologically 
Janapriya Journal of Interdisciplinary Studies, Vol. 6 (December 2017)

sensitive and adaptive system. Wetlands are considered as intermediate ecosystems between land and water incorporating water, soil and organism that are adjusted to the distinctive wet environment resulting in one of the most dynamic ecosystem.

In order to conserve, perspicacious use, and encourage the member countries to list ecological, botanical, zoological, limnological or hydrological significant wetlands as Ramsar sites, Convention on Wetlands of International Importance was signed in Ramsar nominated as Ramsar convention Iran on February 2, 1971 (Ramsar Convention 1971). After successful 17 years of first Ramsar Convention, Nepal signed Ramsar Convention on April 17, 1988 (Kafle \& Savillo, 2009). Till, January 2016, more than 2,220 wetlands with area 2.14 million square kilometers (4-6\% of the total land surface in the world) from 169 member countries have been designated for inclusion in the List of Wetlands of International Importance. Currently, in Nepal, there are 10 Ramsar sites of international importance. Among them, Koshi Tappu wetland is first nominated Ramsar site in Nepal (1987) while Lake clusters of Pokhara Valley are the last nominated Ramsar site ( $2^{\text {nd }}$ Feb 2016) (Ramsar Convention Secretariat, 2016).

Both natural and artificial wetlands are included in Ramsar site of international Importance. Lakes, ponds, riverine floodplains, swamps, and marshes are natural wetlands, while water storage areas and deep-water agricultural lands are artificial wetlands in Nepal. Ramsar sites in Nepal harbor various types of ecosystems and have been providing ecosystem services since many decades (Facility, 2002; Kafle \& Savillo, 2009; Rodrigues, Pilgrim, Lamoreux, Hoffmann, \& Brooks, 2006; Sah \& Heinen, 2002). Nepal wetlands are not only very rich in biodiversity but also are rich sources of water for drinking, fishing, and irrigation. Wetlands/ Ramsar sites of Nepal host endangered species i.e. Asiatic wild buffalo, water buffalo, Greater one-horned rhinoceros, Gangetic dolphin, Swamp deer, Ghadial, Bullfrog. Wetlands are recreation places for migratory birds like Demoiselle crane, cinereous vulture, common greenshank, common 
Ramsar Lakes in the Foothills of ...

teal, Eurasian Curlew, good wall, great cormorant, greater spotted eagle, imperial eagle, Kentish Plover (Bhandari, 2008). In Nepal wetlands have been reported to harbor more than $25 \%$ of total bio diversities (Facility, 2002) . Nepal wetlands (swamp in Kapilvastu) harbor 3 wild species of riceand DNA of these is used frequently to produce hybrid varieties of rice in Nepal (Bhandari, 2008).Wetland ecosystems support diverse and unique habitats. These wetlands provide numerous ecological services but are under tremendous stress due to rapid urbanization, industrialization and agricultural intensification, manifested by the shrinkage in their areal extent, and decline in the hydrological, economic and ecological functions they perform

The objectives of this study are to: a) review the Ramsar Site/wetland of Pokhara - Lekhnath Metropolitan city, b) describe the significance and threats of Ramsar Sites in terms of their geographic distribution and extent, ecosystem benefits and ecological integrity which are considered as biodiversity hub that play crucial role in ecosystem services.

\section{Data and Methods}

Pokhara Lekhnath is a naturally attractive and historical Metropolitan City in Nepal. It is the Headquarter of Province no 4, and is situated 200 kilometers west from Kathmandu, the capital city of Nepal. Recently, it is declared as the biggest Metropolitan city, occupying an area of 464.24 sq. $\mathrm{km}$ which is 9, 18 and 2.5 times larger than Kathmandu, Lalitpur and Bhataratpur metropolitan city respectively (https://en.wikipedia.org/ wiki/Pokhara). It has population of 414,141 with population density of 892.1/Km² ( https://en.wikipedia.org/wiki/Pokhara, Planning \& Secretariat, 2012). The altitude varies from 827 meters $(2,713$ feet $)$ in the southern part to 1,740 meters (5,710 feet) in the northern part (UNDP/ERRRP, No, 2013). It lies in the Mahabharata Range, Midlands and the Great Himalayan Range of Nepal between longitudes $83^{\circ} 48^{\prime} \mathrm{E}$ and $84^{\circ} 13^{\prime} 11^{\prime \prime} \mathrm{E}$ and latitudes $28^{\circ} 4^{\prime} 39^{\prime \prime} \mathrm{N}$ and $28^{\circ} 36^{\prime} 18^{\prime \prime} \mathrm{N}$ (Oli 1996).

Pokhara Metropolitan City is one of the most rapidly urbanizing city of Nepal residing mixture of climatic conditions within the Seti river 
Janapriya Journal of Interdisciplinary Studies, Vol. 6 (December 2017)

watershed. The climatic conditions of the central part of the basin ranges between sub-tropical to cool temperate, whereas the climatic deviations in the northern part ranges from temperate to alpine with high precipitation rate, around $3000 \mathrm{~mm}$ per year (Rimal et al, 2013; Tripathee et al., 2016). This city encompasses nine cluster lakes (Phewa, Begnas, Rupa, Dipang, Maidi, Khaste, Neurani, Kamalpokhari and Gunde) of ecological importance listed as $10^{\text {th }}$ Ramsar Site/ Wetlands (no 2257) bearing an international gratitude and safeguarding the livelihoods and ecosystem.

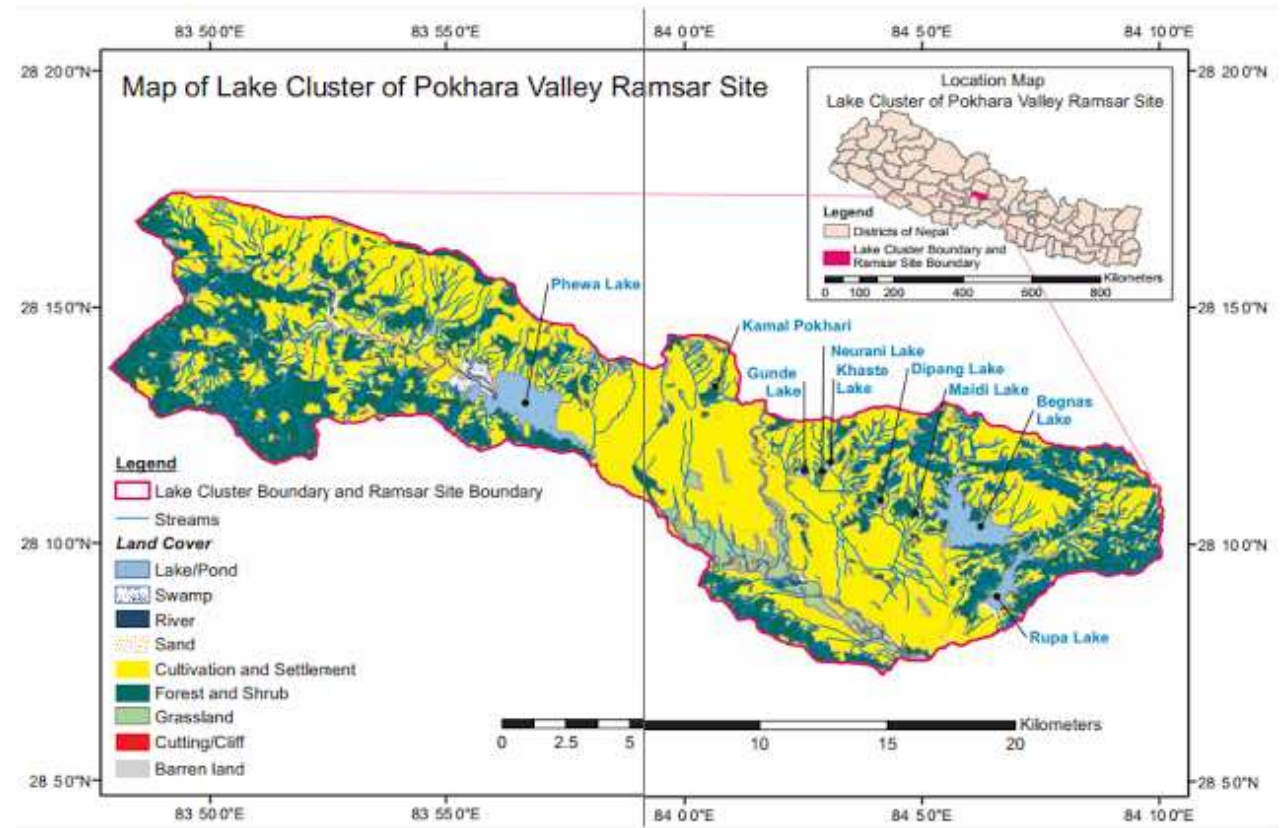

\section{Lake cluster of Pokhara valley}

(Adopted from IUCN, Nepal, 2016)

The information's for the study were collected through review of existing literature, research papers, reports and other relevant online materials through national and international efforts. The study focuses on present location, status, importance and threats of Ramsar Lakes in Pokhara Lekhnath Metropolitan City. 
Ramsar Lakes in the Foothills of ...

Table 1

List of Ramsar Sites in Nepal

\begin{tabular}{lllll}
\hline Name of Ramsar site & Location & $\begin{array}{c}\text { Area in } \\
\text { hector }\end{array}$ & $\begin{array}{l}\text { Elevation } \\
\text { in Meter }\end{array}$ & $\begin{array}{l}\text { Ramsar } \\
\text { Designation Date }\end{array}$ \\
\hline $\begin{array}{l}\text { Beeshajari and associated } \\
\text { lakes }\end{array}$ & Chitwan & 3200 & 285 & $2003 / 08 / 13$ \\
GhodaGhodi Lake & Kailali & 2563 & 205 & $2003 / 08 / 13$ \\
$\begin{array}{l}\text { Gokyo lake and } \\
\begin{array}{l}\text { associated wetland } \\
\text { Jagadishpurreservior }\end{array}\end{array}$ & Solukhumbu & 7770 & 5000 & $2007 / 09 / 23$ \\
$\begin{array}{l}\text { Lake cluster of } \\
\begin{array}{l}\text { Pokhara(8-lakes) } \\
\text { Mai Pokhari }\end{array}\end{array}$ & Kaski & 26106 & 827 & $2016 / 02 / 02$ \\
$\begin{array}{l}\text { Gosaikunda and } \\
\text { associated lakes }\end{array}$ & Ilam & 225 & 195 & $2003 / 08 / 13$ \\
$\begin{array}{l}\text { Phoksundo lake } \\
\text { Koshi Tappu }\end{array}$ & Rasuwa & 1030 & 4700 & $2007 / 09 / 23$ \\
Rara & Sunsari & 17500 & 90 & $1988 / 12 / 17$ \\
\hline Source: & Mugu & 1583 & 2990 & $2007 / 09 / 23$ \\
\hline
\end{tabular}

Source : (https://en.wikipedia.org/wiki/Ramsar_Convention, 2017)

\section{Phewa Lake}

Phewa Lake is the largest lake of Pokhara valley situated in the foot hills of Himalaya at an elevation of $782 \mathrm{~m}$ a.s.l., symbolizing a lake with intense anthropogenic burden from various pollutant and contaminants sources. It bears an external area of $4.35 \mathrm{Km}^{2}$ and extreme depth of $22.5 \mathrm{~m}$ (Sharma et al., 2015,). The major source of water is surrounding catchments and Harpan Khola that flow west to east into the lake. It is regarded as very easy access lake in southern slope of central Himalaya with great anthropogenic density due to various human uses and activities like agricultural inputs (fertilizers and pesticides), fisheries, domestic wastes, recreation and sedimentation, etc. Indigenous anthropogenic events in the watershed of Phewa Lake like traffic, waste burning, agricultural, grazing, fishing, Paragliding etc. are also creating threats on to the aquatic ecosystem (Rupakheti et al., 2017; Sharma et al., 2015). Landslides from 
Janapriya Journal of Interdisciplinary Studies, Vol. 6 (December 2017)

territory of lake, erosion, fragile geology and siltation might drastically alter the chemical composition of lake water influencing the quality of water, lentic and lotic environment and ecosystem (Rai, 2000).

\section{Begnas Lake}

Begnas Lake is the second biggest lake in the Pokhara Valley located in the foot hills of Himalaya at an elevation of $650 \mathrm{~m}$ a.s.l. covering an area of $3.28 \mathrm{~km}^{2}$ containing water volume of $17.96 \times 106 \mathrm{~m}^{3}$ and extreme depth of 10 m (Rai, 2000 \&Rai, A. K. 1995). The chief foundation of the lake water is the catchments and Syankhudi Khola that runs west to south into the lake. It is a versatile Lake and is applicable for irrigation, commercial level fishery and recreation which encompasses dynamic role in lentic ecosystem and environment. However, the lake basin is susceptible to anthropogenic events for instance agricultural inputs, urbanization, boating and human settlements. Moreover, it is a eutrophic lake (Watanabe \& Bhandary, 1988) vulnerable to the regional chemical weathering and atmospheric precipitation inputs that governs the lake chemical feature influencing the ecology integrity and lentic environment (Khadka \& Ramanathan, 2013).

\section{Rupa Lake}

Rupa Lake is the third largest and densely polluted lake of PokharaLekhnath Metropolitan city. This Lake is located in the foot hills of Himalaya at an elevation of $600 \mathrm{~m}$ a.s.l. with an area of $1.35 \mathrm{Km}^{2}$ and average depth of 3m (Rai et al. 1996). This small progressing eutrophic lake (Shrestha, 2017) has Talbesi Khola, as the major source of the lake with sole outlet Tal khola. The existence of 450 diverse species of flora and fauna exposes its diverse biodiversity $(\mathrm{Oli}, 1996)$. This lake assists the large varieties of floral and faunal species and is under the stress of innumerable anthropogenic elements. Biodiversity's of this lake are under numeral threats including trapping, hunting, fishing, natural soil erosion, sedimentation and agricultural inputs, human disturbance, pollution and eutrophication deteriorating the aquatic environments and ecosystem (Jha, 2008). Major floods and landslides have dumped enormous sediments in the lake and its adjoining wetlands, and substantial deforestation around the 
Ramsar Lakes in the Foothills of ...

lake consequences in the degradation of lentic environment (Kunwar \& Devkota, 2012; Lake, 2008; Rai, 2000; Shrestha, 2017).

\section{Depang Lake}

Depang Lake is the third biggest freshwater Lake of Pokhara Metropolitan City situated between green hills with an area of $3.24 \mathrm{Km}^{2}$ and $3-5 \mathrm{~m}$ depth. It is in an elevation of $562 \mathrm{~m}$ from sea level. This is famous for fishing purpose ("Seven Lakes" lekhnath.com). This lake is also influenced by anthropogenic activities, natural erosion and sedimentation.

\section{Khaste Lake}

Khaste Lake is the freshwater lake situated in the Pokhara- Lekhnath Metropolitan city with an area of $2.4 \mathrm{Km}^{2}$ and elevation of $764 \mathrm{~m}$ from sea level The water body covers $1.37 \mathrm{Km}^{2}$ and is used for fish rearing and agriculture. It is also represented as 'Bird Wetland' and famous for observing birds. Its inflow source is Neureni Lake and outflows is Taal Khola. The region is a prospective research midpoint for the inspecting of the birds as diverse species of birds visited this lakes. This indicate its biodiversity importance. It is also affected by fishing, irrigation and agriculture inputs ("Seven Lakes" lekhnath.com).

\section{Maidi, Niureni, Gunde and Kamal Pokhari Lakes}

These are tiny lakes located in Pokhara-Metropolitan city and also play vital role in aquatic ecosystem. These lakes bear area of $0.01 \mathrm{Km}^{2}, 0.02$ $\mathrm{Km}^{2}, 0.08 \mathrm{Km}^{2}$ and $0.02 \mathrm{Km}^{2}$ respectively. Despite of being small, these lakes are significant from the view of ecosystem and environment as they play major role in ecosystem services. They are also highly influenced by anthropogenic activities disturbing the biodiversity ("Seven Lakes" lekhnath.com).

\section{Importance}

Wetlands are reflected as distinctive ecological characteristics providing abundant amenities to humanity and ecosystem (Prasad et al., 2002). Ecosystem imports delivered by the wetlands are water system for 
Janapriya Journal of Interdisciplinary Studies, Vol. 6 (December 2017)

irrigation, fisheries, forest products, water supply for households and recreation.

Multiple ecosystem services comprise carbon sequestration, flood control, ground water recharge, nutrient removal, toxics retention and biodiversity maintenance (Bergh, Barendregt, Ecological-, \& Maltby, 2000).

\section{Multiple-use water services}

Wetlands such as ponds, lakes, and reservoirs affords several and extended use water services that comprises water for irrigation, domestic desires, fisheries and recreational practices, groundwater restore, flood governor and silt detention. Commercial level fish rearing are most common in the lakes of Pokhara.

\section{Carbon sequestration}

Swamps, peat lands and marshes area involve in the significant role of carbon cycle. Wetland sediments/deposits are the durable supplies of carbon and donate nearby $40 \%$ of the global methane emissions bearing the uppermost carbon density in terrestrial ecosystems and comparatively higher dimensions to sequester supplementary carbon dioxide (Lal, 2004; Pant, Rechcigl, \& Adjei, 2003; Upadhyay, Sankhayan, \& Solberg, 2005; Zedler \& Kercher, 2005).Wetlands sequester carbon in high proportions of organic residue inputs and decline the rates of decompositions(Pant et al., 2003).

\section{Pollution reduction}

Wetlands action as descend for pollutants in numerous agricultural and urban landscapes. It is recommended as a low cost measure to decrease point and non-point pollution from environments (Bergh et al., 2000). Riparian wetlands, diminish the nutrient constituent's load from inflow water by discarding nitrate and phosphorus components from surface and subsurface runoff (Verhoeven, Arheimer, Yin, \& Hefting, 2006). 
Ramsar Lakes in the Foothills of ...

\section{Flood regulator}

Wetlands perform an imperative character in flood regulation and control. It traps suspended solids particles and nutrient components that assist to diminish the effects of flooding by arresting water resulting in the decrease of flood water movements (Boyd \& Banzhaf, 2006, 2007).

\section{Biodiversity hotspots}

Unlike, other natural habitat, wetlands are also essential region for biodiversity. It support species diversity by creating natural habitat for sustainable life. Many vertebrates and invertebrates rely on wetlands for completion of life cycle where as some others partly associate with such habitat in particular periods of life cycle. It acts as platform for photosynthesis and recycling the nutrients that display a vital role and assist the food chains. Wetlands are significant breeding regions for wildlife and afford a shelter for migratory birds and aquatic animals (Juliano, 1999). Diverse aquatic plant in the Lake Cluster of Pokhara were sub-merged, free floating, rooted floating and other emerged plant species.

\section{Emergent threat to wetland ecosystem}

Wetland are utmost profoundly used, depended upon and exploited ecosystems for sustainability and welfare of living beings (Molur, Smith, Daniel, \& Darwall, 2011). Loss in the wetland area consequences the adverse effect on the main functions of the ecosystem goods and services accomplished by wetlands (Sah \& Heinen, 2002; Zedler \& Kercher, 2005). Globally, the foremost causes of wetland loss are urbanization, land use changes, reckless irrigation, unscientific infrastructure development, industrial effluent, agricultural runoff and climate change inconsistency (Dudgeon et al., 2015; Jha, 2008; Weber, 1995). In Pokhara, extreme unscientific infrastructure development, land plotting around the periphery of Lakes increases anthropogenic inputs and, decreases the life of biodiversity and aquatic ecosystem. Traffic related emission and sounds influence the chemistry of lakes and threats birds and fishes. Natural erosion, sedimentation, rapid advancement of water Hyacinth and connection of sewage in lakes decrease dissolve oxygen and threatened the 
Janapriya Journal of Interdisciplinary Studies, Vol. 6 (December 2017)

life of lentic environment. Researcher analyses the limnological condition and water chemistry of Phewa, Begnas and Rupa Lake identifying their controlling mechanism in temporal scale. Identifying ions, mercury and trace elements load is important as they transfer and biomagnified $(\mathrm{Hg}$ and Trace metals) when passing through one trophic level to another (Khadka \& Ramanathan, 2013; Sharma et al., 2015). So wetlands conservation is important in order to conserve ecosystem to protect life of human, plants, birds, fish and other aquatic life forms.

\section{Conclusion}

Ecosystem assists diverse and distinctive habitats. Wetland ecosystems benefit topographic and climatic regimes. They are regarded as dynamic measure of hydrological cycle and are extremely fruitful systems in nature. Wetlands not only act as biological diversity hot spot butalso deliver a wide array of ecosystem goods and services. In Pokhara, Lakes afford numerous services, comprising irrigation, domestic water supply, freshwaterfisheries and recreation. They play central role in groundwater recharge, flood control, and carbon sequestration and pollution abatement (Bassi, Kumar, Sharma, \& Pardha-saradhi, 2014). Still, management of wetlands has received in adequate attention. As a result, the wetlands are subjected to massive anthropogenic pressures, including land use changes in the catchment, pollution from industry and households, encroachments, tourism and over exploitation of their natural resources. Research work on sustainable wetlands management must be associated to the limnological aspects, ecological/environmental economics, hydrological and land-use changes in the catchment and socio-economic processes.

\section{Acknowledgement}

The authors are thankful to all the member supporting for collection of papers and sharing ideas.

\section{References}

Bassi, N., Kumar, M. D., Sharma, A., \& Pardha-saradhi, P. (2014). Journal of Hydrology: Regional Studies Status of wetlands in India: A 
Ramsar Lakes in the Foothills of ...

review of extent, ecosystem benefits, threats and management strategies. Journal of Hydrology: Regional Studies, 2, 1-19. https://doi.org/10.1016/j.ejrh.2014.07.001

Bergh, J., Barendregt, T., Ecological-, E. M., \& Maltby, E. (2000). economic analysis of wetlands: scientific integration for management and policy . Ecological Economics THE VALUES OF WETLANDS : LANDSCAPE AND INSTITUTIONAL integration for management and policy. Hnm, 2(September 2015), 56-67. https://doi.org/10.1016/S0921-8009(00)00164-6

Bhandari, B. B. (2008). Wise use of Wetlands in Nepal, (December), 1017.

Boyd, J., \& Banzhaf, S. (2006). What are ecosystem services? The need for standardized environmental accounting units: Ecological Economics of Coastal Disasters - Coastal Disasters Special Section. Ecological Economics, 63(January), 616-626 ST-What are ecosystem services? The nee. https://doi.org/10.1016/j.ecolecon.2007.01.002

Boyd, J., \& Banzhaf, S. (2007). What are ecosystem services? The need for standardized environmental accounting units. Ecological Economics, 63(2-3), 616-626. https://doi.org/10.1016/j.ecolecon.2007.01.002

Byström, O., Andersson, H., \& Gren, M. (2000). Economic criteria for using wetlands as nitrogen sinks under uncertainty. Ecological Economics, 35(1), 35-45.

City, S., \& Rimal, B. (2013). Urbanization and the Decline of Agricultural Land in Pokhara, 5(1), 54-65. https://doi.org/10.5539/jas.v5n1p54

Convention, R. (1971). Wetlands and the Ramsar Convention.

Dudgeon, D., Arthington, A. H., Gessner, M. O., Kawabata, Z., Naiman, R. J., Knowler, D. J., \& Le, C. (2015). Freshwater biodiversity: importance, threats, status and conservation challenges, (2006), 163-182. https://doi.org/10.1017/S1464793105006950

Facility, G. E. (2002). NEPAL BIODIVERSITY STRATEGY His Majesty ' s Government of Nepal Ministry of Forests and Soil Conservation. Nature, 1-117. 
Janapriya Journal of Interdisciplinary Studies, Vol. 6 (December 2017)

Jha, S. (2008). Status and Conservation of Lowland Terai Wetlands in Nepal, 67-77.

Juliano, K. (1999). The Impact of Wetlands on Flood Control in the Red River Valley of Manitoba.

Kafle, G., \& Savillo, I. (2009). Present status of Ramsar sites in Nepal. International Journal of Biodiversity and Conservation, 1(5), 146150. Retrieved from http://www.acadjourn.org/IJBC/PDF/ PDF2009/September/Kafle and Savillo.pdf

Khadka, U. R., \& Ramanathan, A. L. (2013). Major ion composition and seasonal variation in the Lesser Himalayan lake: Case of Begnas Lake of the Pokhara Valley, Nepal. Arabian Journal of Geosciences, 6(11), 4191-4206. https://doi.org/10.1007/s12517012-0677-4

Kunwar, D., \& Devkota, A. (2012). SEASONAL VARIATION ON PHYSIOCHEMICAL PARAMETERS AND MACROPHYTES PRODUCTION OF RUPA LAKE , KASKI , NEPAL, 26, 80-87.

Lake, R. (2008). Status of and Threats to Waterbirds of Rupa Lake, Pokhara, Nepal 1, 1, 2003-2006.

Lal, R. (2004). Carbon sequestration in soils of central Asia. Land Degradation \& Development, 15(6), 563-572. https://doi.org/10.1002/ldr.624

Molur, S., Smith, K. G., Daniel, B. A., \& Darwall, W. R. T. (2011). The status and distribution of Freshwater Biodiversity in the Western Ghats, India. Cambridge, UK and Gland, Switzerland: IUCN, and Coimbatore, India: Zoo Outreach Organisation.

No, U. P. (2013). CSUWN Nepal.

Oli, K. P. (Ed.). (1996). Environmental study of Nepal's Begnas and Rupa lakes. National Conservation Strategy Implementation Project.

Pant, H. K., Rechcigl, J. E., \& Adjei, M. B. (2003). Carbon sequestration in wetlands: $\mathrm{C}$ oncept and estimation. Food, Agriculture and Environment, 1(April), 308-313.

Planning, N., \& Secretariat, C. (2012). National Populatio n and Housing 
Ramsar Lakes in the Foothills of ...

Census 2011 Central Bu reau of Statistics, 1.

Prasad, S. N., Ramachandra, T. V., Ahalya, N., Sengupta, T., Kumar, A., Tiwari, A. K., ... Vijayan, L. (2002). Conservation of wetlands of India - A review. Tropical Ecology, 43(1), 173-186.

Rai, A. K. (2000). Limnological characteristics of subtropical Lakes Phewa, Begnas, and Rupa in Pokhara Valley, Nepal. Limnology, 1(1), 33-46. https://doi.org/10.1007/s102010070027

Rai, A. K. (1995). Bathymetric maps of lakes Phewa, Begnas and Rupa in Pokhara valley, Nepal. Mem Fac Sci Kyoto Univ (Ser Biol), 16, 4954.

Ramsar Convention Secretariat. (2016). An Introduction to the Convention on Wetlands (previously The Ramsar Convention Manual)., 15-18.

Rodrigues, A. S. L., Pilgrim, J. D., Lamoreux, J. F., Hoffmann, M., \& Brooks, T. M. (2006). The value of the IUCN Red List for conservation. Trends in Ecology and Evolution, 21(2), 71-76. https://doi.org/10.1016/j.tree.2005.10.010

Rupakheti, D., Tripathee, L., Kang, S., Sharma, C. M., Paudyal, R., \& Sillanpää, M. (2017). Assessment of water quality and health risks for toxic trace elements in urban Phewa and remote Gosainkunda Lakes, Nepal. Human and Ecological Risk Assessment: An International Journal, 7039(March), 0-0. https://doi.org/10.1080/10807039.2017.1292117

Sah, J. P., \& Heinen, J. T. (2002). Wetland resource use and conservation attitudes among indigenous and migrant peoples in Ghodaghodi Lake area, Nepal. Environmental Conservation, 28(4), 345-356. https://doi.org/10.1017/S0376892901000376

Sharma, C. M., Kang, S., Sillanpää, M., Li, Q., Zhang, Q., Huang, J., ... Paudyal, R. (2015). Mercury and selected trace elements from a remote (gosainkunda) and an urban (Phewa) Lake Waters of Nepal. Water, Air, and Soil Pollution, 226(2). https://doi.org/10.1007/s11270-014-2276-3

Shichang, K., Dahe, Q., Mayewski, P. a., Sneed, S. B., \& Tandong, Y. (2002). Chemical composition of fresh snow on Xixabangma peak, 
Janapriya Journal of Interdisciplinary Studies, Vol. 6 (December 2017)

central Himalaya, during the summer monsoon season. Journal of Glaciology, $\quad 48(161), \quad 337-339$. https://doi.org/10.3189/172756502781831467

Shrestha, S. (2017). Contribution of Rupa Lake for Sustainable Food Security and Local Climate Change, 7, 151-160. https://doi.org/10.17265/2159-5828/2017.03.006

Tripathee, L., Kang, S., Rupakheti, D., Zhang, Q., Huang, J., \& Sillanp????, M. (2016). Water-soluble ionic composition of aerosols at urban location in the foothills of Himalaya, Pokhara Valley, Nepal. Atmosphere, 7(8). https://doi.org/10.3390/atmos7080102

Upadhyay, T. P., Sankhayan, P. L., \& Solberg, B. (2005). A review of carbon sequestration dynamics in the Himalayan region as a function of land-use change and forest/soil degradation with special reference to Nepal. Agriculture, Ecosystems and Environment, 105(3), 449-465. https://doi.org/10.1016/j.agee.2004.09.007

Verhoeven, J. T. A., Arheimer, B., Yin, C., \& Hefting, M. M. (2006). Regional and global concerns over wetlands and water quality. Trends in Ecology and Evolution, 21(2), 96-103. https://doi.org/10.1016/j.tree.2005.11.015

Watanabe, M., \& Bhandary, R. (1988). Studies on Some Lakes Limnological of the Pokhara Variables in Subtropical, 317(317), 71-86.

Weber, K. E. (1995). Status and Management of Watersheds in the Upper Pokhara Valley, Nepal, 19(4), 497-513.

Zedler, J. B., \& Kercher, S. (2005). WETLAND RESOURCES: Status, Trends, Ecosystem Services, and Restorability. Annual Review of Environment and Resources, 30(1), 39-74. https://doi.org/10.1146/annurev.energy.30.050504.144248 